\title{
Double Salt Ionic Liquids Prepared by Mixing Partially Miscible Ionic Liquids: Tuning the Solubility of Lipophilic Molecules
}

\author{
Hui Wang, ${ }^{\mathrm{a}}$ Jorge F. B. Pereira, ${ }^{\mathrm{a}, \dagger}$ Allan S. Myerson, ${ }^{\mathrm{b}}$ and Robin D. Rogers ${ }^{\mathrm{a}, *}$ \\ ${ }^{\mathrm{a}}$ Center for Green Manufacturing and Department of Chemistry, The University of \\ Alabama, Tuscaloosa, AL 35487, USA \\ ${ }^{b}$ Novartis-MIT Center for Continuous Manufacturing and Department of Chemical \\ Engineering, Massachusetts Institute of Technology, 77 Massachusetts Avenue, 66-568, \\ Cambridge, MA 02139, USA \\ *Corresponding author: Tel. +1-205/348-4323; E-mail: rdrogers@ ua.edu \\ ${ }^{\dagger}$ Current address: Department of Bioprocess and Biotechnology, School of \\ Pharmaceutical Sciences, UNESP - Universidade Estadual Paulista, 14801-902 - \\ Araraquara, SP, Brazil

\begin{abstract}
Double Salt Ionic Liquids (DSILs) were prepared by mixing 1ethyl-3-methylimidazolium bis(trifluoromethylsulfonyl)imide $\left(\left[\mathrm{C}_{2} \mathrm{mim}\right]\left[\mathrm{NTf}_{2}\right]\right)$ and trihexyl(tetradecyl)phosphonium bis(trifluoromethylsulfonyl)imide $\left(\left[\mathrm{P}_{66614}\right]\left[\mathrm{NTf}_{2}\right]\right)$ in their miscible range: $\left[\mathrm{C}_{2} \mathrm{mim}\right]_{\mathrm{x}}\left[\mathrm{P}_{66614}\right]_{(1-\mathrm{x})}\left[\mathrm{NTf}_{2}\right](0 \leq \mathrm{x} \leq 0.29) .{ }^{1} \mathrm{H} \mathrm{NMR},{ }^{19} \mathrm{~F}$ NMR, and FT-IR spectroscopic studies indicated that the $\left[\mathrm{NTf}_{2}\right]^{-}$ anions preferentially interact with the $\left[\mathrm{C}_{2} \mathrm{mim}\right]^{+}$cations. Solubility studies showed that solutes with long alkyl chains (e.g., heptane, methyl palmitate), which have good solubility in $\left[\mathrm{P}_{66614}\right]\left[\mathrm{NTf}_{2}\right]$ but are not totally miscible, have tunable solubility in the DSILs and the presence of even minor amounts of $\left[\mathrm{C}_{2} \mathrm{mim}\right]^{+}$significantly decreases their solubility. However, the solubilities of benzene, toluene, 1-octanol, and poly(ethylene glycol) (PEG-300) in $\left[\mathrm{C}_{2} \mathrm{mim}\right]_{\mathrm{x}}\left[\mathrm{P}_{66614}\right]_{(1-\mathrm{x})}\left[\mathrm{NTf}_{2}\right]$ were controlled by their miscibility with $\left[\mathrm{P}_{66614}\right]\left[\mathrm{NTf}_{2}\right]$, and can't be tuned by changing the ion concentrations within the miscibility range.
\end{abstract}

\section{Introduction}

Research on ionic liquids (ILs, generally defined as salts melting below $100{ }^{\circ} \mathrm{C}$ ) has gained considerable attention in the last two decades due to their various applications, including organic synthesis (1), catalysis (2), separations (3), biomass dissolution $(4,5)$, analytical chemistry ( 6 ), electrochemistry as electrolytes in alternative energy generation/storage devices $(7,8)$, etc. It has been the ability to tailor the physicochemical properties of ILs by choice of ions that has accounted for much of the widespread interest in such diverse applications of ILs. Recently, however, the preparation of an even larger and more diverse array of liquids with several different cations and anions, often by simple mixing of salts (9-11) or direct reactions $(12,13)$, has led to an even greater ability to tune the specific physical and chemical properties of these useful systems.

Several recent papers have reported multi-ion liquid systems with the preponderance of these devoted to mixing two liquid ionic liquids to study the unique resultant physical properties $(14,15)$. These "ionic liquid mixtures" which appear to be unique ionic fluids, 
can be easily prepared, but perhaps not so easily understood. Quite similar multi-ion liquids can be prepared by dissolving a solid salt in an IL $(10,11)$ and this has led to another terminology called, "salt in ionic liquid". Recently, we proposed that all such ionic compositions containing more than one cation or anion which are liquid below $100{ }^{\circ} \mathrm{C}$, could be viewed as "Double Salt Ionic Liquids" (DSILs) rather than as simple mixtures of ILs or a salt in an IL (16), and have focused our attention on the use of these systems as tunable separations media.

One of our recent studies to understand DSILs illustrated that indeed the solvent properties of these ionic fluids can be finely tuned by changing the composition and abundance of the ions which results in unique ionic and hydrogen bonded interactions between the ions (17). For instance, in the DSILs prepared by mixing 1-ethyl-3methylimidazolium acetate $\left(\left[\mathrm{C}_{2} \mathrm{mim}\right][\mathrm{OAc}]\right)$ and 1-ethyl-3-methylimidazolium bis(trifluoromethylsulfonyl)imide $\left(\left[\mathrm{C}_{2} \mathrm{mim}\right]\left[\mathrm{NTf}_{2}\right]\right)$, solubility of molecular solvents $(e . g$., EtOAc) and pharmaceuticals (e.g., diphenhydramine), which are good hydrogen bond acceptors, decreases with increase of the acetate anion concentration; while solubility of $\mathrm{H}_{2} \mathrm{O}$ and ibuprofen, which are good hydrogen bond donors, in the DSILs increases with increase of acetate concentration. The different trends of solubilities of various compounds were attributed to the specific interactions between the ions in the DSILs because of the quite different hydrogen bond basicities of the two anions (17).

Non-polar solvents, e.g., heptane and hexane, are widely used as solvents for paints, adhesives, printing inks, degreasing, and insecticides, used for extractive electrospray ionization of 1-hydroxypyrene (18), extraction of organophosphorus pesticides from fresh vegetable samples ( 19 ), dispersion polymerization ( 20 ), manufacturing of pharmaceuticals (21), etc. The ability to significantly change the properties of a solvent is advantageous for chemical processes involving multiple steps (e.g., reactions, extractions/separations, etc.), each of which requires different solvent characteristics (22). Heptane, hexane, and cyclohexane have been shown to be readily dissolved in ILs containing long alkyl chains, such as trihexyl(tetradecyl)phosphonium chloride $\left(\left[\mathrm{P}_{66614}\right][\mathrm{Cl}]\right), \quad\left[\mathrm{P}_{66614}\right][\mathrm{OAc}], \quad$ and 1-butyl-3-methylimidazolium stearate $\left(\left[\mathrm{C}_{4} \mathrm{mim}\right]\left[\mathrm{C}_{18} \mathrm{H}_{35} \mathrm{COO}\right]\right)(23,24)$, however, their solubilities in the commonly studied ILs, such as 1-butyl-3-methylimidazolium hexafluorophosphate $\left(\left[\mathrm{C}_{4} \mathrm{mim}\right]\left[\mathrm{PF}_{6}\right]\right)$, 1-butyl-3methylimidazolium tetrafluoroborate $\left(\left[\mathrm{C}_{4} \mathrm{mim}\right]\left[\mathrm{BF}_{4}\right]\right), \quad\left[\mathrm{C}_{2} \mathrm{mim}\right][\mathrm{OAc}], \quad$ and $\left[\mathrm{C}_{2} \mathrm{mim}\right]\left[\mathrm{NTf}_{2}\right]$ are quite limited $(25,26)$.

Aiming to tune the solubility of non-polar solvents, we investigated DSILs containing the trihexyl(tetradecyl)phosphonium $\left(\left[\mathrm{P}_{66614}\right]^{+}\right.$, Figure 1) cation with long alkyl chains, as ILs containing this cation have good miscibility with non-polar solvents (23). The DSILs were prepared by mixing $\left[\mathrm{C}_{2} \mathrm{mim}\right]\left[\mathrm{NTf}_{2}\right]$ and $\left[\mathrm{P}_{66614}\right]\left[\mathrm{NTf}_{2}\right]$ in their miscible range as these two ILs are not totally miscible with each other (27). Spectroscopic data were collected to understand the interactions between the ions and the solvent properties of the resulting $\left[\mathrm{C}_{2} \mathrm{mim}\right]_{\mathrm{x}}\left[\mathrm{P}_{66614}\right]_{(1-\mathrm{x})}\left[\mathrm{NTf}_{2}\right](0 \leq \mathrm{x} \leq 0.29)$ systems were measured by determining the solubility of heptane, benzene, toluene, 1-octanol, poly(ethylene glycol) (PEG-300), and methyl palmitate as a function of ion composition. 


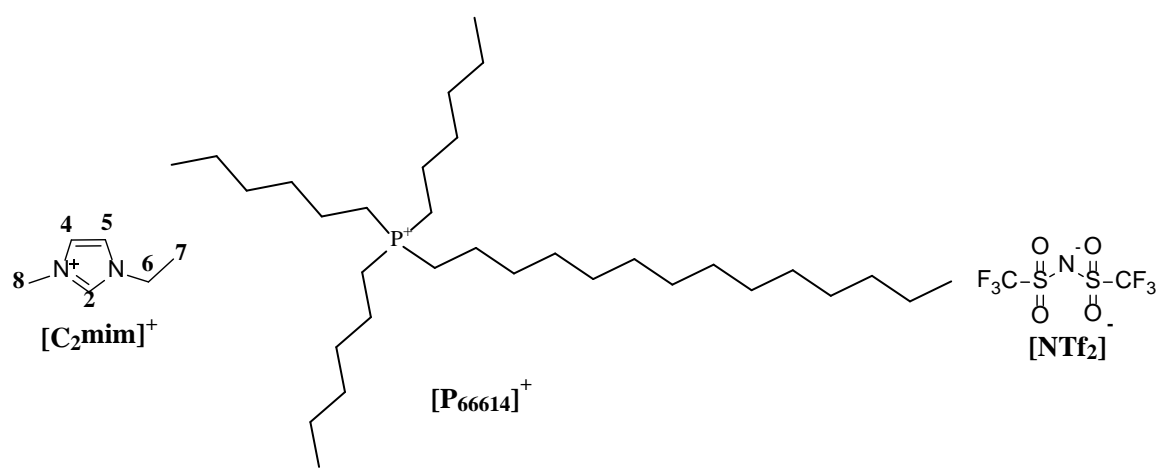

Figure 1. Structures of the ions used to make DSILs of the compositions $\left[\mathrm{C}_{2} \operatorname{mim}\right]_{\mathrm{x}}\left[\mathrm{P}_{66614}\right]_{(1-\mathrm{x})}\left[\mathrm{NTf}_{2}\right](0 \leq \mathrm{x} \leq 0.29)$ : 1-ethyl-3-methylimidazolium $\left(\left[\mathrm{C}_{2} \mathrm{mim}\right]^{+}\right)$, trihexyl(tetradecyl)phosphonium $\left(\left[\mathrm{P}_{66614}\right]^{+}\right)$, and bis(trifluoromethylsulfonyl)imide $\left(\left[\mathrm{NTf}_{2}\right]^{-}\right)$.

\section{Experimental}

\section{$\underline{\text { Chemicals }}$}

The ILs $\left[\mathrm{C}_{2} \mathrm{mim}\right]\left[\mathrm{NTf}_{2}\right]$ and $\left[\mathrm{P}_{66614}\right]\left[\mathrm{NTf}_{2}\right]$ were purchased from Ionic Liquids Technologies Inc. (Tuscaloosa, AL). Before use, the ILs were individually dried to reduce water content to a minimum. Methyl palmitate, dimethyl carbonate, and poly(ethylene glycol) (PEG-300) were obtained from Sigma-Aldrich (Milwaukee, WI), and 1-octanol was purchased from Alfa Aesar (Ward Hill, MA). HPLC-grade benzene with a purity $\geq 99.9 \mathrm{wt} \%$ was obtained from Sigma-Aldrich (St. Louis, MO). Deuterated chloroform $\left(\mathrm{CDCl}_{3}\right)$ and dimethyl sulfoxide (DMSO- $\left.d_{6}\right)$ were purchased from Cambridge Isotope Laboratories, Inc. (Andover, MA). Deionized (DI) water was obtained from a commercial deionizer (Culligan, Northbrook, IL) with specific resistivity of $17.30 \mathrm{M} \Omega$ $\mathrm{cm}$ at $25{ }^{\circ} \mathrm{C}$. All other solvents and reagents (ethyl acetate, acetonitrile, heptane, and toluene) were obtained from Sigma-Aldrich (St. Louis, MO) and used as received.

\section{Mutual Solubility of the ILs}

Solubility of $\left[\mathrm{C}_{2} \mathrm{mim}\right]\left[\mathrm{NTf}_{2}\right]$ in $\left[\mathrm{P}_{66614}\right]\left[\mathrm{NTf}_{2}\right]$ at $25{ }^{\circ} \mathrm{C}$ was measured by adding $\left[\mathrm{C}_{2} \mathrm{mim}\right]\left[\mathrm{NTf}_{2}\right]$ dropwise to $1.0 \mathrm{~g}\left[\mathrm{P}_{66614}\right]\left[\mathrm{NTf}_{2}\right]$ until a turbid solution was obtained. The saturated $\left[\mathrm{C}_{2} \mathrm{mim}\right]\left[\mathrm{NTf}_{2}\right] /\left[\mathrm{P}_{66614}\right]\left[\mathrm{NTf}_{2}\right]$ solution was dissolved in DMSO- $d_{6}$ and analyzed by ${ }^{1} \mathrm{H}$ NMR, and the solubility of $\left[\mathrm{C}_{2} \mathrm{mim}\right]\left[\mathrm{NTf}_{2}\right]$ in $\left[\mathrm{P}_{66614}\right]\left[\mathrm{NTf}_{2}\right]$ was calculated by integration of the imidazolium proton in $\left[\mathrm{C}_{4} \mathrm{mim}\right]^{+}$and the $-\mathrm{CH}_{2}$ protons closest to $\mathrm{P}$ in $\left[\mathrm{P}_{66614}\right]^{+}(28)$, and confirmed from the masses of the two ILs added to the vial. Solubility of $\left[\mathrm{P}_{66614}\right]\left[\mathrm{NTf}_{2}\right]$ in $\left[\mathrm{C}_{2} \mathrm{mim}\right]\left[\mathrm{NTf}_{2}\right]$ was measured following a similar procedure, however, the result reported is based on the mass of the two ILs added to the vial as the small amount of $\left[\mathrm{P}_{66614}\right]\left[\mathrm{NTf}_{2}\right]$ which can saturate $1.0 \mathrm{~g}\left[\mathrm{C}_{2} \mathrm{mim}\right]\left[\mathrm{NTf}_{2}\right]$, is close to the detection limit of ${ }^{1} \mathrm{H}$ NMR.

\section{Preparation of the DSILs}

Approximately $6 \mathrm{~g}$ samples of the DSILs $\left[\mathrm{C}_{2} \mathrm{mim}\right]_{\mathrm{x}}\left[\mathrm{P}_{66614}\right]_{(1-\mathrm{x})}\left[\mathrm{NTf}_{2}\right]$ (where $\mathrm{x}$ is the $\left[\mathrm{C}_{2} \mathrm{mim}\right]^{+} /\left[\mathrm{NTf}_{2}\right]^{-}$molar ratio, $0 \leq \mathrm{x} \leq 0.29$ ) were prepared in the miscible range of the 
two parent ILs, by mass addition of the corresponding amount of each IL with $\mathrm{x}=0.09$, $0.17,0.23$, and 0.29 . The DSILs were stirred thoroughly for $1 \mathrm{~h}$, then dried under high vacuum at $60{ }^{\circ} \mathrm{C}$ for $8 \mathrm{~h}$ and stored in a vacuum desiccator.

\section{$\underline{\text { Miscibility and Solubility Determinations }}$}

Miscibilities of organic solvents with $\left[\mathrm{C}_{2} \mathrm{mim}\right]\left[\mathrm{NTf}_{2}\right]$ or $\left[\mathrm{P}_{66614}\right]\left[\mathrm{NTf}_{2}\right]$ were tested by adding the organic solvent dropwise into $0.5 \mathrm{~g} \mathrm{IL}$ and vortexed. If the solution was still clear when the molar ratio of the organic solvent to the IL reached 25:1, the IL and organic solvent were considered to be totally miscible. If a turbid solution was obtained after adding one more drop of the organic solvent, the IL was considered to be saturated and the solubility of the organic solvent in the IL was determined by ${ }^{1} \mathrm{H}$ NMR based on integration of appropriate signals.

The solubilities of heptane and PEG-300 in the DSILs was determined by adding each solute drop by drop to $0.5 \mathrm{~g}$ of each DSIL until the solution just became turbid, at which point the DSIL was saturated. The saturated heptane/DSIL solutions were analyzed by ${ }^{1} \mathrm{H}$ NMR, and the solute/DSIL molar ratios were calculated through direct integration of appropriate signals. Solubility of PEG-300 in the DSIL was quite limited and reported based on the mass of PEG-300 and DSILs added to the vial.

The solubilities of 1-octanol, benzene, and toluene in the DSILs were determined by adding each solute dropwise to $0.5 \mathrm{~g}$ of each DSIL until the molar ratio of the organic solvent to DSIL reached 25:1. No turbid solutions were obtained for any of these three solvents and they were determined to be totally miscible.

The solubility of methyl palmitate in the DSILs was tested by loading $0.05 \mathrm{~g}$ of the solid methyl palmitate into a vial loaded with $0.5 \mathrm{~g}$ DSIL and stirring. If all the added methyl palmitate was dissolved, an additional amount was added until no more could dissolve and the DSIL was saturated. The solution was then separated from the undissolved particles using a PTFE filter with pore size of $0.45 \mu \mathrm{m}$, and the saturated solutions were dissolved in DMSO- $d_{6}$ and analyzed by ${ }^{1} \mathrm{H}$ NMR. The solute/DSIL molar ratios were calculated through direct integration of appropriate signals.

\section{Spectroscopic Techniques}

${ }^{1} \mathrm{H}$ NMR spectra were taken utilizing a Bruker Avance $500 \mathrm{MHz}$ NMR spectrometer (Karlsruhe, Germany). The DSILs, saturated toluene/[ $\left.\mathrm{C}_{2} \mathrm{mim}\right]\left[\mathrm{NTf}_{2}\right]$, saturated benzene $/\left[\mathrm{C}_{2} \mathrm{mim}\right]\left[\mathrm{NTf}_{2}\right]$, saturated 1-octanol/[C $\left.\mathrm{C}_{2} \mathrm{mim}\right]\left[\mathrm{NTf}_{2}\right]$, and saturated heptane/DSIL solutions were loaded solventless in a flame-sealed capillary, and the spectra were collected at $25{ }^{\circ} \mathrm{C}$ using $\mathrm{CDCl}_{3}$ as the external lock. As the saturated methyl palmitate/DSIL solutions were viscous, these solutions were dissolved in DMSO- $d_{6}$ and spectra were collected at $25{ }^{\circ} \mathrm{C}$. The ${ }^{19} \mathrm{~F}$ NMR spectra of the DSILs were obtained on a Bruker Avance $360 \mathrm{MHz}$ NMR spectrometer (Karlsruhe, Germany), using trifluoroacetic $\mathrm{acid} / \mathrm{CDCl}_{3}$ solution as the external lock.

Infrared spectroscopic measurements of the DSILs were taken on neat samples by utilizing a Bruker Alpha Attenuated Total Reflectance-Fourier Transform Infrared (ATRFTIR) spectrometer (Billerica, MA), allowing for direct observation of the liquids. Spectra were obtained in the range of $v_{\max }=400-4000 \mathrm{~cm}^{-1}$.

\section{$\underline{\text { Water Content Measurements }}$}


Water contents of $\left[\mathrm{C}_{2}\right.$ mim $]\left[\mathrm{NTf}_{2}\right],\left[\mathrm{P}_{66614}\right]\left[\mathrm{NTf}_{2}\right]$, and the DSILs were measured using a Karl Fischer titrator (Mettler Toledo C20 coulometric KF) using AQUASTAR CombiCoulomat fritless methanol solution, supplied by Merck \& Co. Inc. (Whitehouse Station, NJ) as titrant.

\section{Results and Discussion}

We first measured the mutual solubility of $\left[\mathrm{C}_{2} \mathrm{mim}\right]\left[\mathrm{NTf}_{2}\right]$ and $\left[\mathrm{P}_{66614}\right]\left[\mathrm{NTf}_{2}\right]$ at $25{ }^{\circ} \mathrm{C}$. The results showed that 1 mole $\left[\mathrm{P}_{66614}\right]\left[\mathrm{NTf}_{2}\right]$ can dissolve 0.43 mole $\left[\mathrm{C}_{2} \mathrm{mim}\right]\left[\mathrm{NTf}_{2}\right]$, which is in accordance with the literature (27). However, the solubility of $\left[\mathrm{P}_{66614}\right]\left[\mathrm{NTf}_{2}\right]$ in $\left[\mathrm{C}_{2} \mathrm{mim}\right]\left[\mathrm{NTf}_{2}\right]$ is quite limited at $c a .0 .03 \mathrm{~mol} / \mathrm{mol}\left[\mathrm{C}_{2} \mathrm{mim}\right]\left[\mathrm{NTf}_{2}\right]$. We thus, studied the DSILs comprised of these ILs in the $\left[\mathrm{C}_{2} \mathrm{mim}\right]^{+} /\left[\mathrm{NTf}_{2}\right]^{-}$molar ratio $(\mathrm{x})$ range of 0 to $0.29\left(\mathrm{x}=0.29\right.$ corresponds to mixing $\left[\mathrm{C}_{2} \mathrm{mim}\right]\left[\mathrm{NTf}_{2}\right]$ and $\left[\mathrm{P}_{66614}\right]\left[\mathrm{NTf}_{2}\right]$ in a $0.4: 1$ molar ratio near saturation).

The ILs were dried to water contents of $802.1 \mathrm{ppm}\left(\left[\mathrm{C}_{2} \mathrm{mim}\right]\left[\mathrm{NTf}_{2}\right]\right)$ and $302.1 \mathrm{ppm}$ $\left(\left[\mathrm{P}_{66614}\right]\left[\mathrm{NTf}_{2}\right]\right)$ as measured by Karl Fischer titration, and mixed by mass addition to prepare ca. $6 \mathrm{~g}$ samples of the DSILs $\left[\mathrm{C}_{2} \mathrm{mim}\right]_{\mathrm{x}}\left[\mathrm{P}_{66614}\right]_{(1-\mathrm{x})}\left[\mathrm{NTf}_{2}\right]$ with molar ratios of $\left[\mathrm{C}_{2} \mathrm{mim}\right]^{+} /\left[\mathrm{NTf}_{2}\right]^{-}(\mathrm{x})$ of $0.09,0.17,0.23$, and 0.29 . The DSILs were stirred for $1 \mathrm{~h}$, then dried under high vacuum at $60{ }^{\circ} \mathrm{C}$ for $8 \mathrm{~h}$. The final water content of each DSIL indicated all systems to have less than 810 ppm water in all cases (Table 1).

TABLE 1. Water content and solubility data for $\left[\mathrm{C}_{2} \mathrm{mim}\right]\left[\mathrm{NTf}_{2}\right],\left[\mathrm{P}_{66614}\right]\left[\mathrm{NTf}_{2}\right]$, and $\left[\mathrm{C}_{2} \mathrm{mim}\right]_{\mathrm{x}}\left[\mathrm{P}_{66614}\right]_{(1-\mathrm{x})}\left[\mathrm{NTf}_{2}\right](0 \leq \mathrm{x} \leq 0.29)$.

\begin{tabular}{|c|c|c|c|c|c|c|c|}
\hline \multirow[b]{2}{*}{ IL or DSIL } & \multirow{2}{*}{$\begin{array}{c}\text { Water } \\
\text { content } \\
(\text { ppm) }\end{array}$} & \multicolumn{6}{|c|}{ Solubility (mol solute/mol DSIL) } \\
\hline & & $\begin{array}{l}\text { PEG- } \\
\text { 300* }\end{array}$ & Heptane & $\begin{array}{l}\text { Methyl } \\
\text { palmitate }\end{array}$ & $\begin{array}{c}\text { 1- } \\
\text { Octanol }\end{array}$ & Benzene & Toluene \\
\hline$\left[\mathrm{P}_{66614}\right]\left[\mathrm{NTf}_{2}\right]$ & 302.1 & 0.36 & 8.25 & 1.15 & Miscible & Miscible & Miscible \\
\hline$\left[\mathrm{C}_{2} \operatorname{mim}\right]_{0.09}\left[\mathrm{P}_{66614}\right]_{0.91}\left[\mathrm{NTf}_{2}\right]$ & 495.8 & 0.34 & 5.32 & 0.91 & Miscible & Miscible & Miscible \\
\hline$\left[\mathrm{C}_{2} \mathrm{mim}\right]_{0.17}\left[\mathrm{P}_{66614}\right]_{0.83}\left[\mathrm{NTf}_{2}\right]$ & 464.7 & 0.36 & 4.30 & 0.82 & Miscible & Miscible & Miscible \\
\hline$\left[\mathrm{C}_{2} \mathrm{mim}\right]_{0.23}\left[\mathrm{P}_{66614}\right]_{0.77}\left[\mathrm{NTf}_{2}\right]$ & 695.0 & 0.29 & 3.45 & 0.74 & Miscible & Miscible & Miscible \\
\hline$\left[\mathrm{C}_{2} \mathrm{mim}_{0.29}\left[\mathrm{P}_{66614}\right]_{0.71}\left[\mathrm{NTf}_{2}\right]\right.$ & 605.5 & 0.31 & 0.63 & 0.65 & Miscible & Miscible & Miscible \\
\hline$\left[\mathrm{C}_{2} \operatorname{mim}\right]\left[\mathrm{NTf}_{2}\right]$ & 802.1 & Miscible & 0.02 & 0.0 & 0.09 & 3.25 & 1.87 \\
\hline
\end{tabular}

*The unit of solubility of PEG-300 is mol repeating unit/mol DSIL.

\section{$\underline{\text { Spectroscopic Studies }}$}

NMR spectroscopy was used to understand the interactions between the ions in $\left[\mathrm{C}_{2} \mathrm{mim}\right]_{\mathrm{x}}\left[\mathrm{P}_{66614}\right]_{(1-\mathrm{x})}\left[\mathrm{NTf}_{2}\right](0 \leq \mathrm{x} \leq 0.29)$ as NMR chemical shifts in ILs reflect interionic interactions (29). ${ }^{1} \mathrm{H} \mathrm{NMR}$ data for $\left[\mathrm{C}_{2} \mathrm{mim}\right]_{\mathrm{x}}\left[\mathrm{P}_{66614}\right]_{(1-\mathrm{x})}\left[\mathrm{NTf}_{2}\right]$ were collected by loading the neat samples in capillaries using $\mathrm{CDCl}_{3}$ as external lock and were compared to those of $\left[\mathrm{C}_{2} \mathrm{mim}\right]\left[\mathrm{NTf}_{2}\right]$ and $\left[\mathrm{P}_{66614}\right]\left[\mathrm{NTf}_{2}\right]$ (Figure 2). The upfield chemical shifts of the imidazolium ring protons of the $\left[\mathrm{C}_{2} \mathrm{mim}\right]^{+}$cation $(\mathrm{H}-2, \mathrm{H}-4$, and $\mathrm{H}-5)$ as a function of the increasing $\left[\mathrm{C}_{2} \mathrm{mim}\right]^{+} /\left[\mathrm{NTf}_{2}\right]^{-}$molar ratio (Figure $3 \mathrm{a}$ ) indicate that the $\left[\mathrm{C}_{2} \mathrm{mim}\right]^{+}$cations in 
the DSILs have more/stronger hydrogen bonding and Coulombic interactions than in the parent IL. The number and strength of these interactions decreases as $\mathrm{x}$ increases since statistically there are more $\left[\mathrm{C}_{2} \mathrm{mim}\right]^{+}$cations to compete for each $\left[\mathrm{NTf}_{2}\right]^{-}$anion with increasing $\mathrm{X}$.

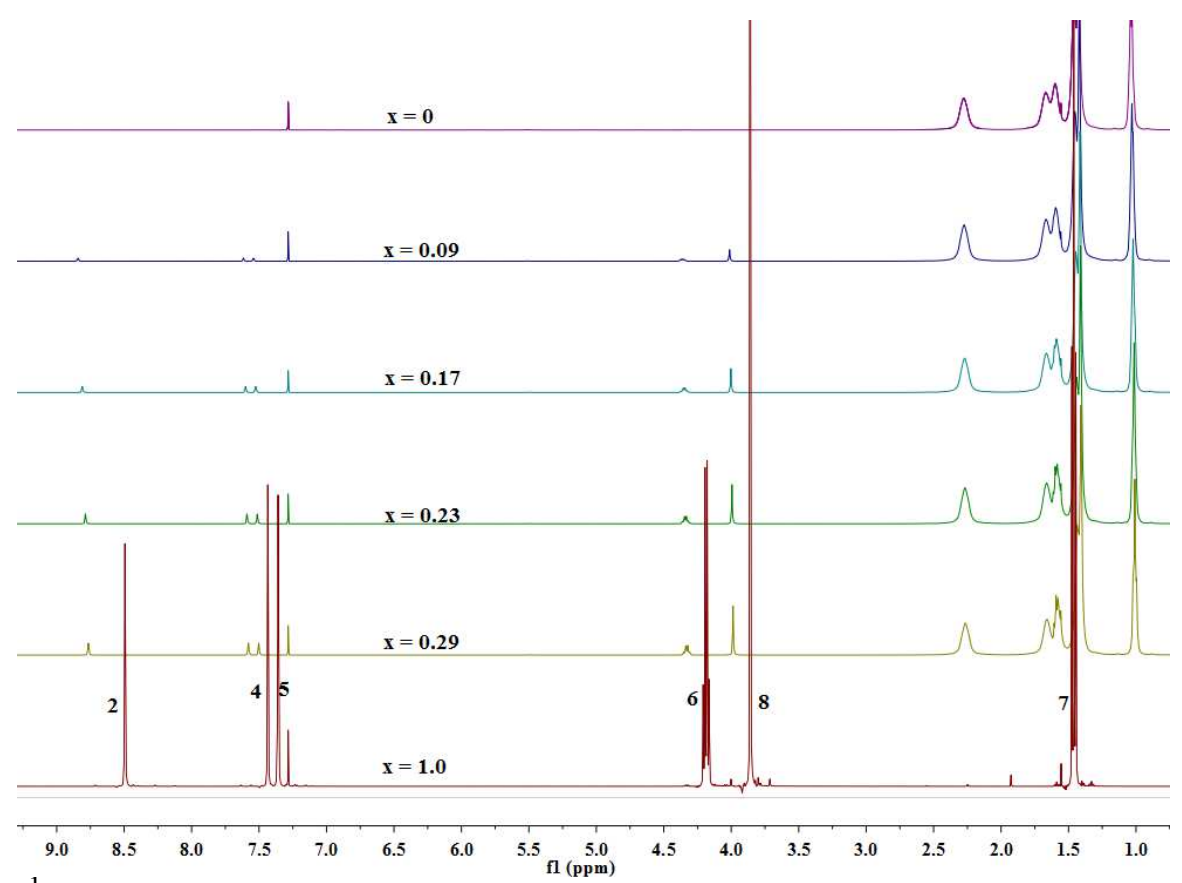

Figure 2. ${ }^{1} \mathrm{H}$ NMR spectra of $\left[\mathrm{C}_{2} \mathrm{mim}\right]_{\mathrm{x}}\left[\mathrm{P}_{66614}\right]_{(1-\mathrm{x})}\left[\mathrm{NTf}_{2}\right]$ at $25{ }^{\circ} \mathrm{C}$ using $\mathrm{CDCl}_{3}$ as external lock. (Zero $(\mathrm{x})$ corresponds to $\left[\mathrm{P}_{66614}\right]\left[\mathrm{NTf}_{2}\right]$ and $\mathrm{x}=1.0$ to $\left[\mathrm{C}_{2} \mathrm{mim}\right]\left[\mathrm{NTf}_{2}\right]$.)
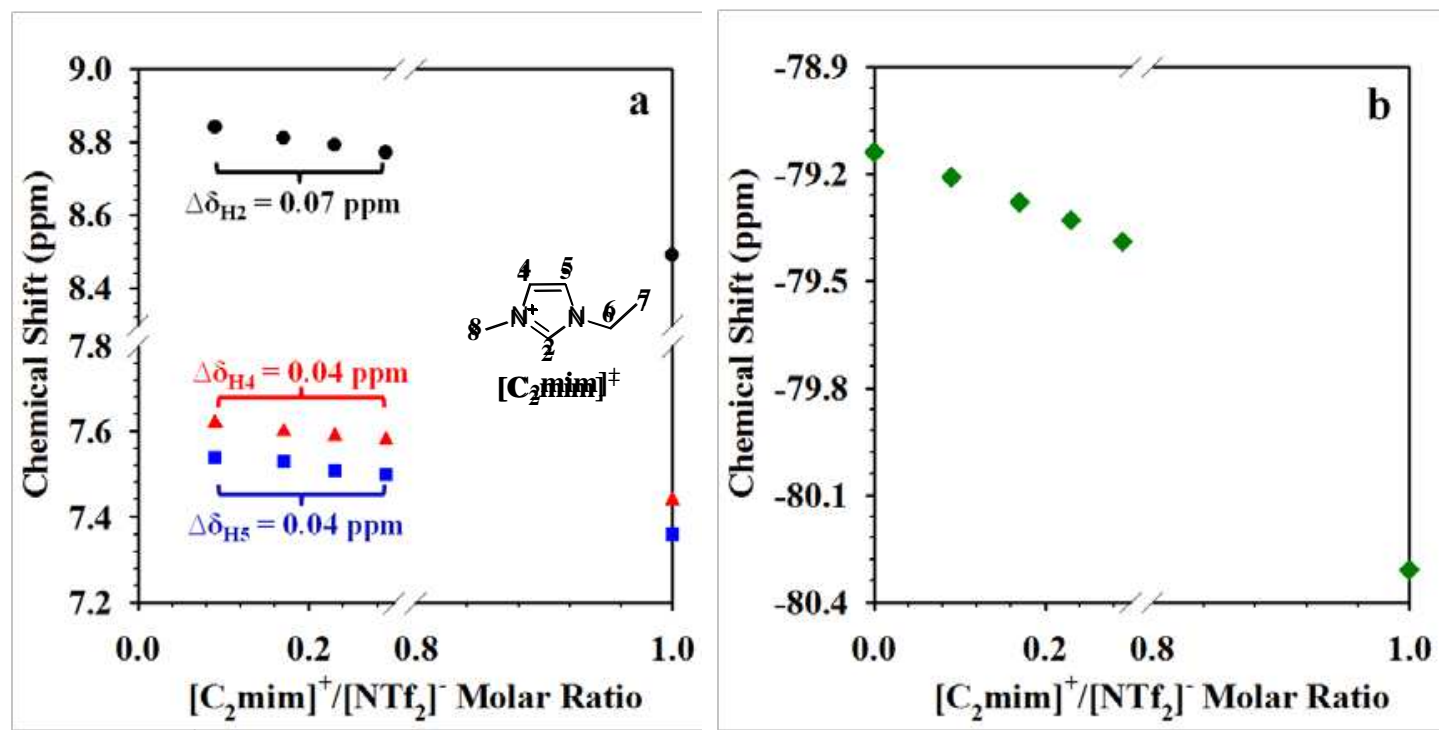

Figure 3. a) ${ }^{1} \mathrm{H}$ NMR chemical shifts of the imidazolium ring protons $(\bullet-\mathrm{H}-2 ; \boldsymbol{\Delta}-\mathrm{H}-4$; a-H-5) and b) ${ }^{19} \mathrm{~F}$ NMR chemical shifts in $\left[\mathrm{C}_{2} \mathrm{mim}\right]_{\mathrm{x}}\left[\mathrm{P}_{66614}\right]_{(1-\mathrm{x})}\left[\mathrm{NTf}_{2}\right]$. (Zero on the $\mathrm{x}$ axis corresponds to $\left[\mathrm{P}_{66614}\right]\left[\mathrm{NTf}_{2}\right]$ and 1.0 to $\left[\mathrm{C}_{2} \mathrm{mim}\right]\left[\mathrm{NTf}_{2}\right]$.)

The $\left[\mathrm{C}_{2} \mathrm{mim}\right]^{+}$cation has short alkyl groups, a more delocalized, but more accessible positive charge, and is a hydrogen bond donor, compared to the more lipophilic, charge shielded $\left[\mathrm{P}_{66614}\right]^{+}$cation ( 30$)$. One would therefore expect, that the cation-anion interactions in $\left[\mathrm{C}_{2} \mathrm{mim}\right]\left[\mathrm{NTf}_{2}\right]$ would be stronger than in $\left[\mathrm{P}_{66614}\right]\left[\mathrm{NTf}_{2}\right]$, and that as 
$\left[\mathrm{C}_{2} \mathrm{mim}\right]\left[\mathrm{NTf}_{2}\right]$ is added to $\left[\mathrm{P}_{66614}\right]\left[\mathrm{NTf}_{2}\right]$, the $\left[\mathrm{NTf}_{2}\right]^{-}$anions would preferentially interact with the $\left[\mathrm{C}_{2} \mathrm{mim}\right]^{+}$cations via Coulombic and weak hydrogen bonding interactions. As the concentration of $\left[\mathrm{C}_{2} \mathrm{mim}\right]^{+}$increases from $\mathrm{x}=0.09$ to 0.29 , each $\left[\mathrm{C}_{2} \mathrm{mim}\right]^{+}$cation will interact with fewer $\left[\mathrm{NTf}_{2}\right]^{-}$anions, resulting in the upfield shifts of the imidazolium protons $(17,31)$ indicating fewer hydrogen bonds and weaker Coulombic interactions as $\mathrm{x}$ increases. Notably, the upfield shift of the $\mathrm{H}-2$ proton is $c a$. twice that of $\mathrm{H}-4$ or $\mathrm{H}-5$, which can be attributed to the fact that although all three hydrogen atoms are affected relatively equally by hydrogen bonding interactions, the major Coulombic interactions (above and below the imidazolium ring) are concentrated near C-2 and thus $\mathrm{H}-2$ is more affected by these interactions (17).

Conversely, the ${ }^{1} \mathrm{H}$ NMR spectra in Figure 2 show no obvious chemical shifts of the protons in the phosphonium cations (peaks $c a$. 1.03, 1.41, 1.59, 1.68, and $2.27 \mathrm{ppm}$ ). This reflects the nature of the interactions between the $\left[\mathrm{P}_{66614}\right]^{+}$cations, with long alkyl chains, and the charge diffuse $\left[\mathrm{NTf}_{2}\right]^{-}$anions (32) which are very weak even in neat $\left[\mathrm{P}_{66614}\right]\left[\mathrm{NTf}_{2}\right](30)$.

${ }^{19} \mathrm{~F}$ NMR spectra of $\left[\mathrm{C}_{2} \mathrm{mim}\right]_{x}\left[\mathrm{P}_{66614}\right]_{(1-x)}\left[\mathrm{NTf}_{2}\right]$ (Figure 4) were collected by loading the neat samples in capillaries using trifluoroacetic acid (TFA)/ $\mathrm{CDCl}_{3}$ solution as external lock. TFA was used as the reference standard and the chemical shifts of the DSILs were compared to those of $\left[\mathrm{C}_{2} \mathrm{mim}\right]\left[\mathrm{NTf}_{2}\right]$ and $\left[\mathrm{P}_{66614}\right]\left[\mathrm{NTf}_{2}\right]$. The ${ }^{19} \mathrm{~F}$ chemical shifts as a function of the $\left[\mathrm{C}_{2} \mathrm{mim}\right]^{+} /\left[\mathrm{NTf}_{2}\right]^{-}$molar ratio (Figure $3 \mathrm{~b}$ ) indicate upfield shifts, suggesting that with increasing $\left[\mathrm{C}_{2} \mathrm{mim}\right]^{+}$concentration each anion can interact with more of this cation resulting in more hydrogen bonding and stronger Coulombic interactions (33). Taken together, the NMR data suggests preferential interactions between the $\left[\mathrm{NTf}_{2}\right]^{-}$anions and $\left[\mathrm{C}_{2} \mathrm{mim}\right]^{+}$cations in $\left[\mathrm{C}_{2} \mathrm{mim}\right]_{\times}\left[\mathrm{P}_{66614}\right]_{(1-\mathrm{x})}\left[\mathrm{NTf}_{2}\right]$.

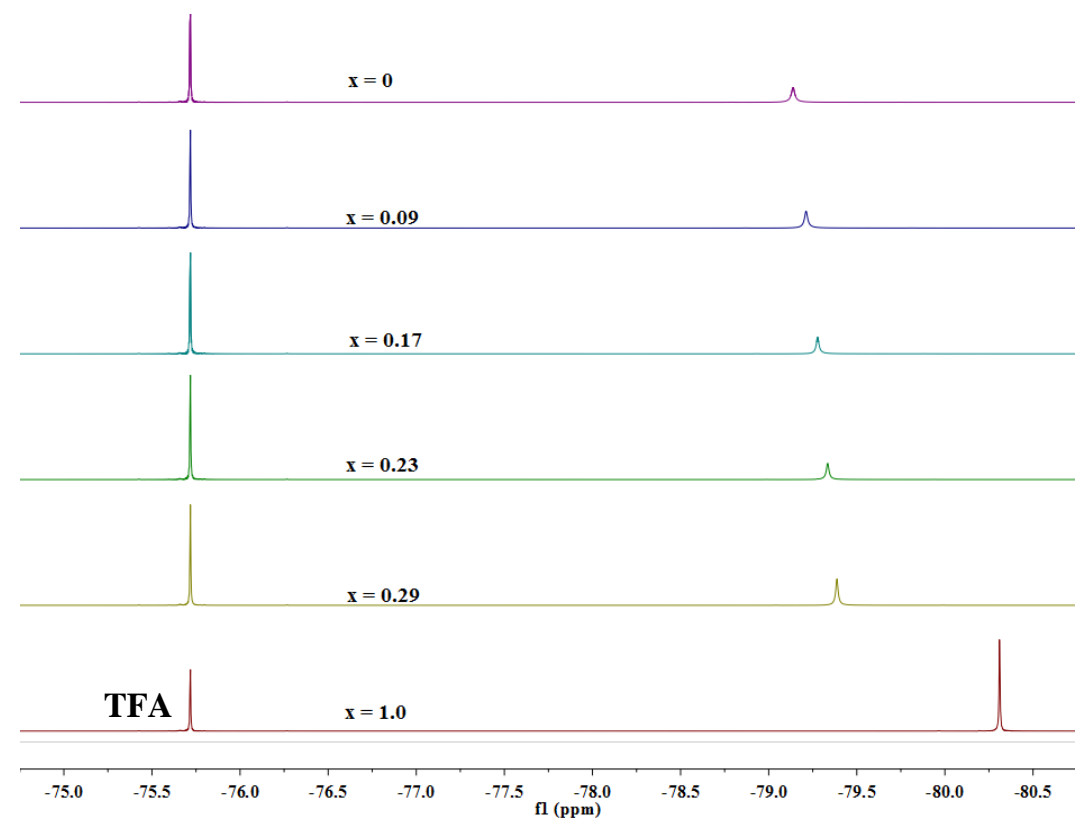

Figure 4. ${ }^{19} \mathrm{~F}$ NMR spectra of $\left[\mathrm{C}_{2} \mathrm{mim}\right]_{\times}\left[\mathrm{P}_{66614}\right]_{(1-\mathrm{x})}\left[\mathrm{NTf}_{2}\right]$ at $25{ }^{\circ} \mathrm{C}$ using trifluoroacetic $\mathrm{acid} / \mathrm{CDCl}_{3}$ as external lock. (Zero $(\mathrm{x})$ corresponds to $\left[\mathrm{P}_{66614}\right]\left[\mathrm{NTf}_{2}\right]$ and $\mathrm{x}=1.0$ to $\left.\left[\mathrm{C}_{2} \mathrm{mim}\right]\left[\mathrm{NTf}_{2}\right].\right)$

To confirm the trends noted in the NMR data, the DSILs were further analyzed by ATR-FTIR (Figure 5). The anion's $\mathrm{S}=\mathrm{O}$ symmetric vibration $\left(c a .1131 \mathrm{~cm}^{-1}(34)\right)$ should be sensitive to the electrostatic environment and indeed with increasing $\left[\mathrm{C}_{2} \mathrm{mim}\right]^{+}$ 
concentration, a small redshift of the characteristic $\mathrm{S}=\mathrm{O}$ vibration indicating less double bond character of $\mathrm{S}=\mathrm{O}$ was observed from $1134 \mathrm{~cm}^{-1}$ for $\mathrm{x}=0$ to $1131 \mathrm{~cm}^{-1}$ for $\mathrm{x}=1.0$. As the $\left[\mathrm{C}_{2} \mathrm{mim}\right]^{+}$concentration (x) increases, there are more $\left[\mathrm{C}_{2} \mathrm{mim}\right]^{+}$cations for each $\left[\mathrm{NTf}_{2}\right]^{-}$to interact with, resulting in weaker $\mathrm{S}=\mathrm{O}$ bonds. As the $\left[\mathrm{NTf}_{2}\right]^{-}$is charge diffuse (32) the interactions between $\left[\mathrm{C}_{2} \mathrm{mim}\right]^{+}$and $\left[\mathrm{NTf}_{2}\right]^{-}$are still quite weak and the redshift is quite small (only $3 \mathrm{~cm}^{-1}$ ) although quite clearly observed. The FT-IR data thus, also suggest that the $\left[\mathrm{NTf}_{2}\right]^{-}$anions preferentially interact with $\left[\mathrm{C}_{2} \mathrm{mim}\right]^{+}$cations rather than $\left[\mathrm{P}_{66614}\right]^{+}$.
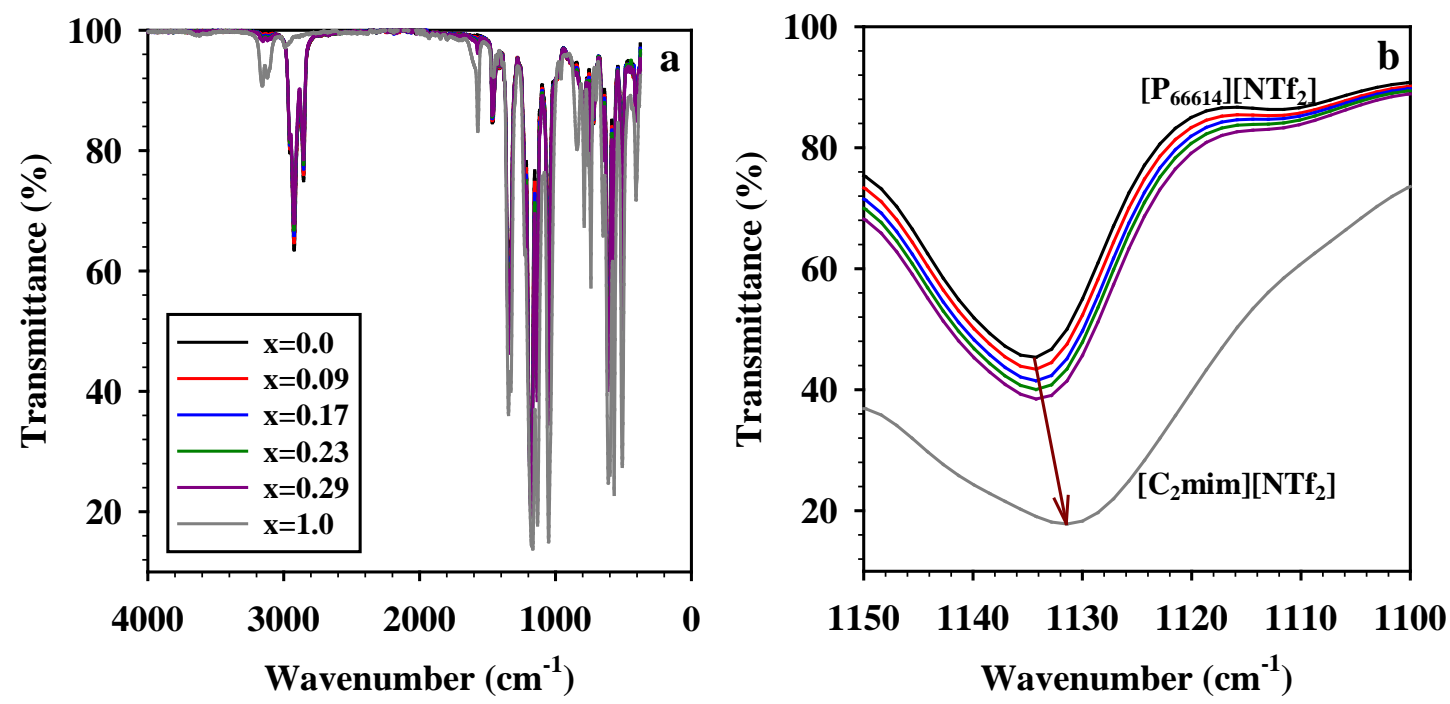

Figure 5. FT-IR spectra of $\left[\mathrm{C}_{2} \mathrm{mim}\right]_{\times}\left[\mathrm{P}_{66614}\right]_{(1-\mathrm{x})}\left[\mathrm{NTf}_{2}\right]$ : a) full spectra; $\left.\mathrm{b}\right) \mathrm{S}=\mathrm{O}$ vibration (from top to bottom: $\mathrm{x}=0.0,0.09,0.17,0.23,0.29,1.0$, respectively; zero (x) corresponds to $\left[\mathrm{P}_{66614}\right]\left[\mathrm{NTf}_{2}\right]$ and 1.0 to $\left[\mathrm{C}_{2} \mathrm{mim}\right]\left[\mathrm{NTf}_{2}\right]$.)

If conversely, one considers adding $\left[\mathrm{P}_{66614}\right]\left[\mathrm{NTf}_{2}\right]$ to $\left[\mathrm{C}_{2} \operatorname{mim}\right]\left[\mathrm{NTf}_{2}\right]$, the $\left[\mathrm{P}_{66614}\right]^{+}$ cation would have to weaken the $\left[\mathrm{C}_{2} \mathrm{mim}\right]^{+} /\left[\mathrm{NTf}_{2}\right]^{-}$interactions to form a solution. Since the $\left[\mathrm{P}_{66614}\right]^{+}$cation exhibits even weaker interactions with the $\left[\mathrm{NTf}_{2}\right]^{-}$anion, the solubility of $\left[\mathrm{P}_{66614}\right]\left[\mathrm{NTf}_{2}\right]$ in $\left[\mathrm{C}_{2} \mathrm{mim}\right]\left[\mathrm{NTf}_{2}\right]$ is quite limited. However, since the $\left[\mathrm{C}_{2} \mathrm{mim}\right]^{+}$cation has stronger interactions with the anion, more $\left[\mathrm{C}_{2} \mathrm{mim}\right]\left[\mathrm{NTf}_{2}\right]$ can be dissolved in $\left[\mathrm{P}_{66614}\right]\left[\mathrm{NTf}_{2}\right]$.

\section{$\underline{\text { Miscibility/Solubility of Organic Solvents }}$}

The miscibilities of ethyl acetate (EtOAc), acetonitrile $\left(\mathrm{CH}_{3} \mathrm{CN}\right)$, dimethyl carbonate (DMC), PEG-300, heptane, 1-octanol, benzene, and toluene with $\left[\mathrm{C}_{2} \operatorname{mim}\right]\left[\mathrm{NTf}_{2}\right]$ and $\left[\mathrm{P}_{66614}\right]\left[\mathrm{NTf}_{2}\right]$ were examined prior to testing with any DSILs (Figure 6). The small polar, aprotic solvents, EtOAc, $\mathrm{CH}_{3} \mathrm{CN}$, and DMC are totally miscible with both ILs. PEG-300 is totally miscible with $\left[\mathrm{C}_{2} \mathrm{mim}\right]\left[\mathrm{NTf}_{2}\right]$, in accordance with our previous report which showed that $\left[\mathrm{C}_{2} \mathrm{mim}\right][\mathrm{Cl}]$ is totally miscible with PEGs with low molecular weights, e.g., PEG-1000 (35). The imidazolium ring hydrogen atoms (particularly the C-2 proton) can interact with the ether oxygens and to a lesser extent with the terminal $\mathrm{OH}$ groups of the PEGs (36), resulting in the total miscibility of PEG-300 and $\left[\mathrm{C}_{2} \mathrm{mim}\right]\left[\mathrm{NTf}_{2}\right]$. However, PEG-300 has limited solubility in $\left[\mathrm{P}_{66614}\right]\left[\mathrm{NTf}_{2}\right]$ as this IL is neither a good hydrogen bond donor nor a good hydrogen bond acceptor. 

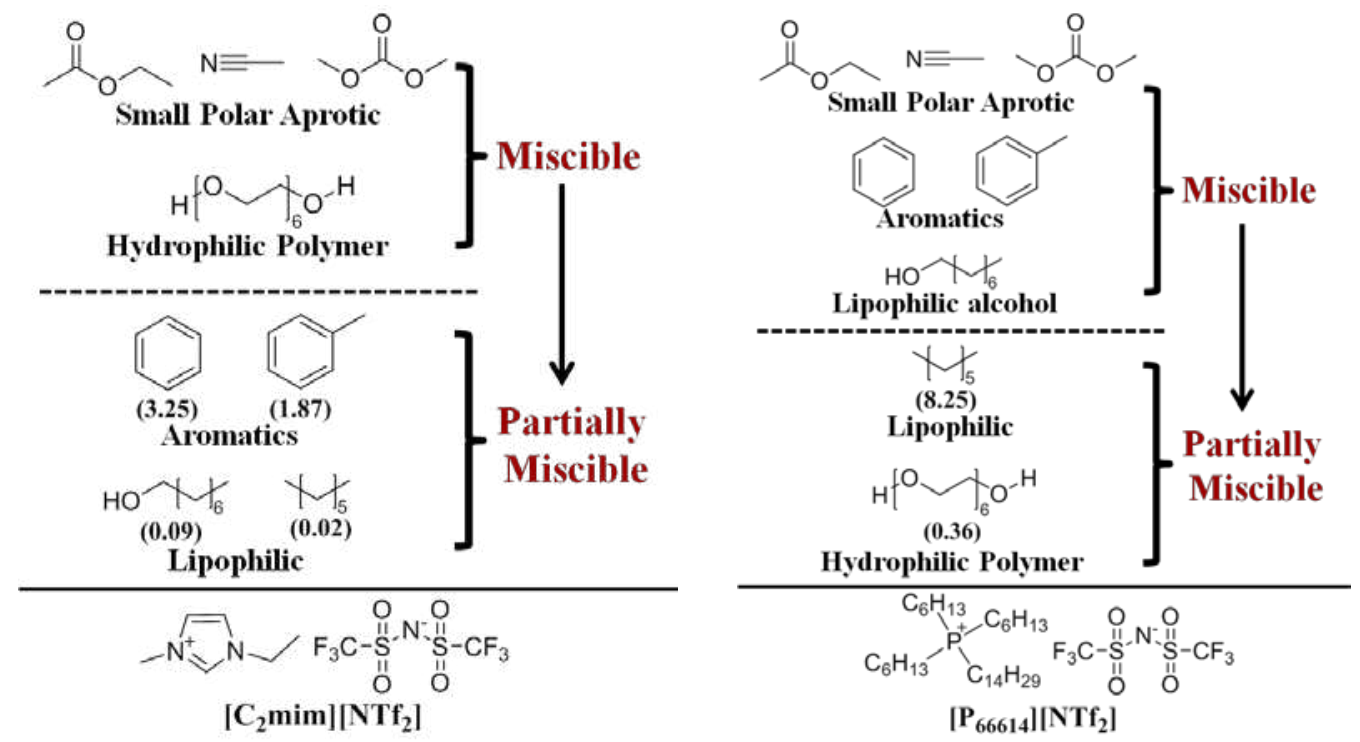

Figure 6. Solubilites of the organic solvents in $\left[\mathrm{C}_{2} \mathrm{mim}\right]\left[\mathrm{NTf}_{2}\right]$ and $\left[\mathrm{P}_{66614}\right]\left[\mathrm{NTf}_{2}\right]$. Numbers under the structures are the solubility of the corresponding solute in the IL in $\mathrm{mol} / \mathrm{mol} \mathrm{IL}$; for PEG-300, the solubility unit is mol repeating ethylene oxide unit/mol IL.

Conversely, the solubility of heptane in $\left[\mathrm{C}_{2} \mathrm{mim}\right]\left[\mathrm{NTf}_{2}\right]$ is quite limited $(0.02 \mathrm{~mol} / \mathrm{mol}$ IL), however 1 mole $\left[\mathrm{P}_{66614}\right]\left[\mathrm{NTf}_{2}\right]$ can dissolve 8.25 mole heptane. 1-Octanol is totally miscible with $\left[\mathrm{P}_{66614}\right]\left[\mathrm{NTf}_{2}\right]$ and its solubility in $\left[\mathrm{C}_{2} \mathrm{mim}\right]\left[\mathrm{NTf}_{2}\right]$ is only $0.09 \mathrm{~mol} / \mathrm{mol} \mathrm{IL}$. The desirable solubilities of heptane and 1-octanol in $\left[\mathrm{P}_{66614}\right]\left[\mathrm{NTf}_{2}\right]$ are attributed to the interactions between the non-polar regions of the IL and that of the organic solvent (37).

Both benzene and toluene are totally miscible with $\left[\mathrm{P}_{66614}\right]\left[\mathrm{NTf}_{2}\right]$ as a result of the weak interactions between the $\left[\mathrm{P}_{66614}\right]^{+}$cations and $\left[\mathrm{NTf}_{2}\right]^{-}$anions (38), while their solubilities in $\left[\mathrm{C}_{2} \mathrm{mim}\right]\left[\mathrm{NTf}_{2}\right]$ are only $3.25 \mathrm{~mol} / \mathrm{mol} \mathrm{IL}$ and $1.87 \mathrm{~mol} / \mathrm{mol} \mathrm{IL}$, respectively, indicating the formation of liquid clathrates $(38,39)$. Liquid clathrate formation and ultimate aromatic solubility are controlled by the strength of cation-anion interactions (38), where stronger ionic interactions lead to lower aromatic solubility.

Results (Table 1) on solubility measurements of PEG-300, heptane, 1-octanol, benzene, and toluene in $\left[\mathrm{C}_{2} \mathrm{mim}\right]_{\mathrm{x}}\left[\mathrm{P}_{66614}\right]_{(1-\mathrm{x})}\left[\mathrm{NTf}_{2}\right](0 \leq \mathrm{x} \leq 0.29)$ showed that 1-octanol, benzene, and toluene are totally miscible with the DSILs $\left[\mathrm{C}_{2} \mathrm{mim}\right]_{\mathrm{x}}\left[\mathrm{P}_{66614}\right]_{(1-\mathrm{x})}\left[\mathrm{NTf}_{2}\right](0 \leq$ $\mathrm{x} \leq 0.29$ ), and their solubilities can't be tuned by changing the ion concentration in the DSILs. The same was observed for PEG-300, where one drop of PEG-300 can saturate $0.5 \mathrm{~g}\left[\mathrm{C}_{2} \mathrm{mim}\right]_{\mathrm{x}}\left[\mathrm{P}_{66614}\right]_{(1-\mathrm{x})}\left[\mathrm{NTf}_{2}\right]$, and the solubility of PEG-300 cannot be tuned.

The solubility of heptane in the DSILs is shown in Figure 7a. With increase of the $\left[\mathrm{C}_{2} \mathrm{mim}\right]^{+} /\left[\mathrm{NTf}_{2}\right]^{-}$molar ratio, the solubility of heptane decreases, up to its solubility limit in $\left[\mathrm{C}_{2} \mathrm{mim}\right]\left[\mathrm{NTf}_{2}\right](0.02 \mathrm{~mol} / \mathrm{mol} \mathrm{IL})$. The presence of even small amounts of $\left[\mathrm{C}_{2} \mathrm{mim}\right]^{+}$ significantly reduce the solubility of heptane in $\left[\mathrm{C}_{2} \mathrm{mim}\right]_{\mathrm{x}}\left[\mathrm{P}_{66614}\right]_{(1-\mathrm{x})}\left[\mathrm{NTf}_{2}\right]$ as discussed below. 

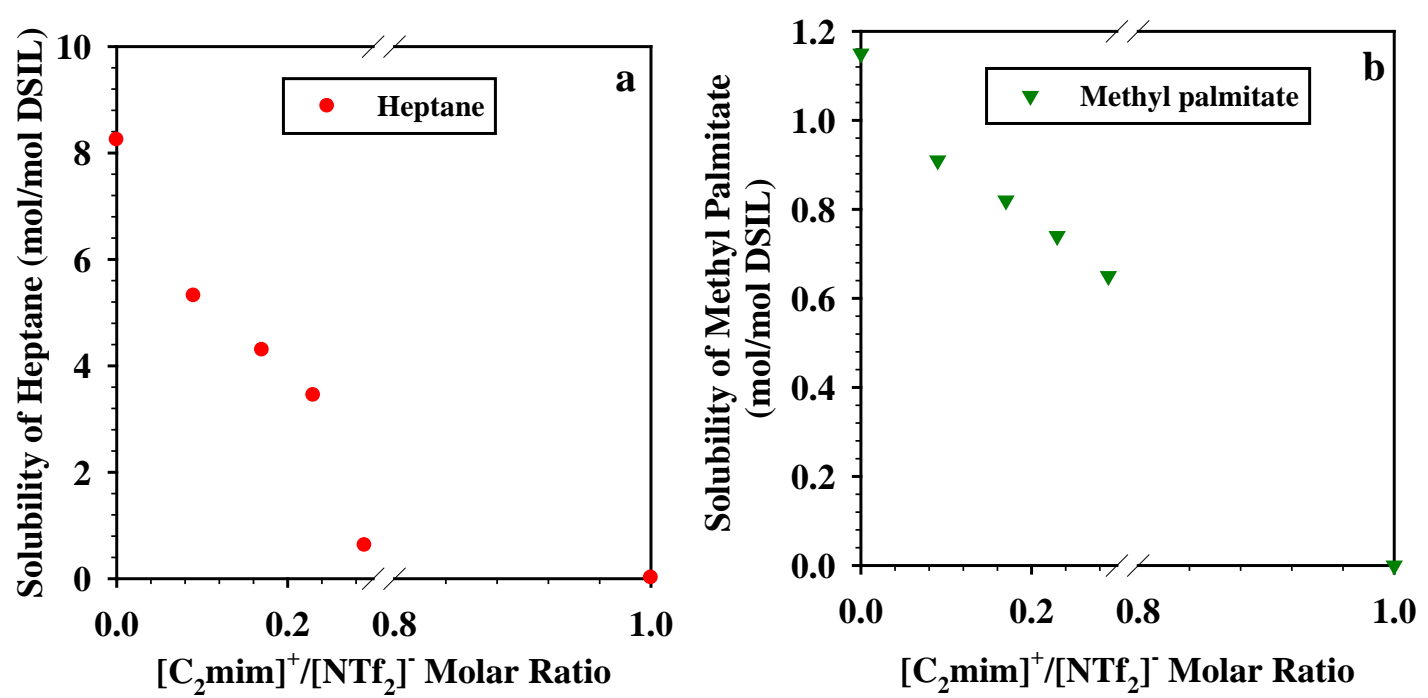

Figure 7. Solubility of heptane (a) and methyl palmitate (b) in $\left[\mathrm{C}_{2} \mathrm{mim}\right]_{\mathrm{x}}\left[\mathrm{P}_{66614}\right]_{(1-\mathrm{x})}\left[\mathrm{NTf}_{2}\right]$ as a function of $\left[\mathrm{C}_{2} \mathrm{mim}\right]^{+}$concentration. (Zero on the $\mathrm{x}$ axis corresponds to $\left[\mathrm{P}_{66614}\right]\left[\mathrm{NTf}_{2}\right]$ and 1.0 to $\left[\mathrm{C}_{2} \mathrm{mim}\right]\left[\mathrm{NTf}_{2}\right]$.)

Methyl palmitate, widely applied in leather and daily-use chemical industries, was chosen as a model compound and its solubility in the DSILs is shown in Table 1 and Figure 7b. As expected, methyl palmitate, with a long alkyl chain, can be readily dissolved in $\left[\mathrm{P}_{66614}\right]\left[\mathrm{NTf}_{2}\right]$, but not in $\left[\mathrm{C}_{2} \mathrm{mim}\right]\left[\mathrm{NTf}_{2}\right]$. With increase of the $\left[\mathrm{C}_{2} \mathrm{mim}\right]^{+}$ concentration in the DSILs, the solubility of methyl palmitate decreases.

The solubility results indicate that compounds with long alkyl chains, e.g., heptane, methyl palmitate, that have desirable solubility but not totally miscible with $\left[\mathrm{P}_{66614}\right]\left[\mathrm{NTf}_{2}\right]$ can be tuned in the DSILs $\left[\mathrm{C}_{2} \mathrm{mim}\right]_{\mathrm{x}}\left[\mathrm{P}_{66614}\right]_{(1-\mathrm{x})}\left[\mathrm{NTf}_{2}\right](0 \leq \mathrm{x} \leq 0.29)$ by changing the ion composition. In other cases, the solvent properties of $\left[\mathrm{C}_{2} \mathrm{mim}\right]_{\mathrm{x}}\left[\mathrm{P}_{66614}\right]_{(1-}$ ${ }_{x}\left[\mathrm{NTf}_{2}\right](0 \leq \mathrm{x} \leq 0.29)$ are determined by the properties of only $\left[\mathrm{P}_{66614}\right]\left[\mathrm{NTf}_{2}\right]$. Because of the limited amount of $\left[\mathrm{C}_{2} \mathrm{mim}\right]^{+}$in $\left[\mathrm{C}_{2} \mathrm{mim}\right]_{\mathrm{x}}\left[\mathrm{P}_{66614}\right]_{(1-\mathrm{x})}\left[\mathrm{NTf}_{2}\right]$ (x can only reach $\sim 0.29$ ) and its smaller volume compared to the bulky $\left[\mathrm{P}_{66614}\right]^{+}$cation, the $\left[\mathrm{C}_{2} \mathrm{mim}\right]^{+}$cations do not interact as much with the compounds that are totally miscible with or virtually have no solubility in $\left[\mathrm{P}_{66614}\right]\left[\mathrm{NTf}_{2}\right]$. In this case, the presence of the $\left[\mathrm{P}_{66614}\right]^{+}$cation will control the solvation ability of the DSILs.

\section{Conclusions}

DSILs, $\left[\mathrm{C}_{2} \mathrm{mim}\right]_{\mathrm{x}}\left[\mathrm{P}_{66614}\right]_{(1-\mathrm{x})}\left[\mathrm{NTf}_{2}\right](0 \leq \mathrm{x} \leq 0.29)$, were prepared by mixing $\left[\mathrm{C}_{2} \mathrm{mim}\right]\left[\mathrm{NTf}_{2}\right]$ and $\left[\mathrm{P}_{66614}\right]\left[\mathrm{NTf}_{2}\right]$ in their miscible range. Spectroscopic analyses revealed preferential interactions, including both Coulombic interactions and hydrogen bonding, between the $\left[\mathrm{NTf}_{2}\right]^{-}$anions and the $\left[\mathrm{C}_{2} \mathrm{mim}\right]^{+}$cations. The interactions between the $\left[\mathrm{C}_{2} \mathrm{mim}\right]^{+}$cations and $\left[\mathrm{NTf}_{2}\right]^{-}$anions vs. those between $\left[\mathrm{P}_{66614}\right]^{+}$cations and $\left[\mathrm{NTf}_{2}\right]^{-}$ anions account for the limited solubilities of $\left[\mathrm{C}_{2} \mathrm{mim}\right]\left[\mathrm{NTf}_{2}\right]$ and $\left[\mathrm{P}_{66614}\right]\left[\mathrm{NTf}_{2}\right]$. Solubility studies show that compounds with long alkyl chains (e.g., heptane, methyl palmitate), which have good solubility in $\left[\mathrm{P}_{66614}\right]\left[\mathrm{NTf}_{2}\right]$ but are not totally miscible with this IL, have tunable solubility in the prepared DSILs, and the presence of minor amounts of $\left[\mathrm{C}_{2} \mathrm{mim}\right]^{+}$significantly decreases the solubility of heptane or methyl palmitate. The solubilities of PEG-300, 1-octanol, benzene, and toluene in $\left[\mathrm{C}_{2} \mathrm{mim}\right]_{\mathrm{x}}\left[\mathrm{P}_{66614}\right]_{(1-\mathrm{x})}\left[\mathrm{NTf}_{2}\right]$ 
were controlled by their miscibility with $\left[\mathrm{P}_{66614}\right]\left[\mathrm{NTf}_{2}\right]$, and cannot be tuned by changing the ion concentration. These kinds of DSILs provide systems with tunable solvent properties for non-polar, lipophilic solvents with long alkyl chains.

\section{Acknowledgments}

We thank the Novartis-Massachusetts Institute of Technology (MIT) Center for Continuous Manufacturing (CCM) for financial support.

\section{References}

1. A. D. Sawant, D. G. Raut, N. B. Darvatkar and M. M. Salunkhe, Green Chem. Lett. Rev., 4, 41 (2011).

2. H. Olivier-Bourbigou, L. Magna and D. Morvan, Appl. Catal. A: Gen., 373, 1 (2010).

3. M. D. Joshi and J. L. Anderson, RSC Adv., 2, 5470 (2012).

4. R. P. Swatloski, S. K. Spear, J. D. Holbrey and R. D. Rogers, J. Am. Chem. Soc., 124, 4974 (2002).

5. Y. Qin, X. Lu, N. Sun and R. D. Rogers, Green Chem., 12, 968 (2010).

6. T. D. Ho, C. Zhang, L. W. Hantao and J. L. Anderson, Anal. Chem., 86, 262 (2014).

7. T. J. Abraham, D. R. MacFarlane and J. M. Pringle, Chem. Commun., 47, 6260 (2011).

8. P. C. Howlett, D. R. MacFarlane and A. F. Hollenkamp, Electrochem. Solid-State Lett., 7, A97 (2004).

9. H. Niedermeyer, J. P. Hallett, I. J. Villar-Garcia, P. A. Hunt and T. Welton, Chem. Soc. Rev., 41, 7780 (2012).

10. A. B. Pereiro, J. M. M. Araújo, F. S. Oliveira, C. E. S. Bernardes, J. M. S. S. Esperança, J. N. C. Lopes, I. M. Marrucho and L. P. N. Rebelo, Chem. Commun., 48, 3656 (2012).

11. M. Y. Lui, L. Crowhurst, J. P. Hallett, P. A. Hunt, H. Niedermeyer and T. Welton, Chem. Sci., 2, 1491 (2011).

12. M. Smiglak, N. J. Bridges, M. Dilip and R. D. Rogers, Chem. Eur. J., 14, 11314 (2008).

13.G. Gurau, H. Wang, Y. Qiao, X. Lu, S. Zhang and R. D. Rogers, Pure Appl. Chem., 84, 745 (2012).

14.A. M. Pinto, H. Rodríguez, Y. J. Colón, A. Arce, Jr., A. Arce and A. Soto, Ind. Eng. Chem. Res., 52, 5975 (2013).

15. J. N. C. Lopes, T. C. Cordeiro, J. M. S. S. Esperança, H. J. R. Guedes, S. Huq, L. P. N. Rebelo and K. R. Seddon, J. Phys. Chem. B, 109, 3519 (2005).

16. G. Chatel, J. F. B. Pereira, V. Debbeti, H. Wang and R. D. Rogers, Green Chem., 16, 2051 (2014).

17. H. Wang, J. W. Brantley, G. Chatel, J. Shamshina, S. P. Kelley, J. F. B. Pereira, V. Debbeti, A. S. Myerson and R. D. Rogers, 2014, in preparation.

18. X. Li, X. Fang, Z. Yu, G. Sheng, M. Wu, J. Fu, F. Yan and H. Chen, Anal. Methods, 4, 1212 (2012).

19. X. Zhao, X. Xu, R. Su, H. Zhang and Z. Wang, J. Chromatogr. A, 1229, 6 (2012).

20. S. M. Klein, V. N. Manoharan, D. J. Pine and F. F. Lange, Colloid Polym. Sci., 
282, 7 (2003).

21. A. Gupta, Y. Singh, K. S. Srinivas, G. Jain, V. B. Sreekumar and V. P. Semwal, J. Pharm. Bioallied Sci., 2, 32 (2010).

22. V. Blasucci, C. Dilek, H. Huttenhower, E. John, V. Llopis-Mestre, P. Pollet, C. A. Eckert and C. L. Liotta, Chem. Commun., 116 (2009).

23. M. Blesic, J. N. C. Lopes, M. F. C. Gomes and L. P. N. Rebelo, Phys. Chem. Chem. Phys., 12, 9685 (2010).

24. J. Zhang, Q. Zhang, B. Qiao and Y. Deng, J. Chem. Eng. Data, 52, 2277 (2007).

25. R. Ryan, Organic Synthesis in Ionic Liquids, Dissertation for Master Degree, Dublin City University (2003).

26. H. Wang, G. Gurau, S. P. Kelley, A. S. Myerson and R. D. Rogers, RSC Adv., 3, 10019 (2013).

27. A. Arce, M. J. Earle, S. P. Katdare, H. Rodríguez and K. R. Seddon, Chem. Commun., 2548 (2006).

28. M. Lin, M. Tesconi and M. Tischler, Int. J. Pharm., 369, 47 (2009).

29. S. Chen, R. Vijayaraghavan, D. R. MacFarlane and E. I. Izgorodina, J. Phys. Chem. B., 117, 3186 (2013).

30. D. Thompson, S. Coleman, D. Diamond and R. Byrne, Phys. Chem. Chem. Phys., 13, 6156 (2011).

31. M. Wierzejewska-Hnat, Z. Mielke and H. Ratajczak, J. C. S. Faraday II, 76, 834 (1980).

32. C. M. Forsyth, D. R. MacFarlane, J. J. Golding, J. Huang, J. Sun and M. Forsyth, Chem. Mater., 14, 2103 (2002).

33. I. Nicotera, C. Oliviero, W. A. Henderson, G. B. Appetecchi and S. Passerini, J. Phys. Chem. B., 109, 22814 (2005).

34. M. Herstedt, M. Smirnov, P. Johansson, M. Chami, J. Grondin, L. Servant and J. C. Lassègues, J. Raman Spectrosc., 36, 762 (2005).

35. H. Rodríguez, M. Francisco, M. Rahman, N. Sun and R. D. Rogers, Phys. Chem. Chem. Phys., 11, 10916 (2009).

36. K. R. Seddon, J. Chem. Technol. Biotechnol., 68, 351 (1997).

37. M. Blesic, J. N. C. Lopes, M. F. C. Gomes and L. P. N. Rebelo, Phys. Chem. Chem. Phys., 12, 9685 (2010).

38. J. F. B. Pereira, L. A. Flores, H. Wang and R. D. Rogers, Chem. Eur. J., 2014, submitted.

39. J. D. Holbrey, W. M. Reichert, M. Nieuwenhuyzen, O. Sheppard, C. Hardacre and R. D. Rogers, Chem. Commun., 476 (2003). 